\title{
Pande Besi Ethics in Transactions and Heirloom Production Rituals
}

\author{
Siti Mardiyah \\ Universitas Trunojoyo Madura \\ email: mardiyahst@gmail.com \\ Robiatul Auliyah \\ Universitas Trunojoyo Madura \\ email: robiatul.auliyah@trunojoyo.ac.id
}

\begin{abstract}
This study seeks to reveal the application of business ethics in the traditional Marsyudi blacksmith business in Paterongan Village. This study uses qualitative methods with a case study approach. The informants in this study were four, namely one main informant as the blacksmith owner and three supporting informants who were employees and customers. This research site is carried out at the Marsyudi traditional blacksmith business site, namely in Tok Koneng Hamlet, Paterongan Village, Galis District, Bangkalan Regency. The results of this study indicate that the application of business ethics to traditional Marsyudi blacksmith business is good. First, Marsyudi's traditional blacksmith business implements a belief value in the implementation of the down payment payment system, the value of giving equal prices in
\end{abstract}


the heirloom selling price and the value of freedom of choice in credit payment transactions made by buyers. Second, the application of ritual ethics before carrying out heirloom production. Rituals in heirloom production that are applied to his efforts are jhejeh rituals, rituals for distributing porridge or sticky rice, reading Basmalah and bathing keris heirloom by using flower water. All of these rituals are intended for the craftsman to be safe and produce good quality heirloom products. These findings are in line with the theory of teleology because the purpose of business ethics carried out by the traditional Marsyudi blacksmith business is for the good, not for evil.

[Penelitian ini mengungkapkan seperti apa etika pande besi yang masih bertahan hingga saat ini. Pande besi ini dikelola oleh bapak Marsyudi di Desa Paterongan. Penelitian ini menggunakan metode kualitatif dengan pendekatan studi kasus. Informan dalam penelitian ini ada empat, yaitu satu informan utama sebagai pemilik pande besi dan tiga informan pendukung yang merupakan karyawan dan pelanggan. Situs penelitian ini dilakukan di tempat usaha pande besi tradisional Marsyudi, yaitu di Dusun Tok Koneng, Desa Paterongan, Kecamatan Galis, Kabupaten Bangkalan. Hasil penelitian ini menunjukkan bahwa penerapan etika pande besi tradisional Marsyudi secara umum sudah baik. Pertama, usaha pande besi tradisional Marsyudi menerapkan nilai kepercayaan dalam penerapan sistem pembayaran uang muka, nilai pemberian kesamaan harga dalam harga jual pusaka dan nilai kebebasan memilih dalam transaksi pembayaran secara kredit yang dilakukan pembeli. Kedua, penerapan etika ritual sebelum melakukan produksi pusaka. Ritual-ritual dalam produksi pusaka yang diterapkan pada usahanya yaitu ritual jhejeh, ritual pembagian bubur atau ketan, pembacaan basmalah dan memandikan pusaka keris dengan menggunakan air kembang. Semua ritual tersebut bertujuan agar si pengrajin selamat dan menghasilkan produk pusaka yang berkualitas bagus. Temuan-temuan tersebut sejalan dengan teori teleologi karena tujuan dari etika bisnis yang dijalankan oleh usaha pande besi tradisional Marsyudi untuk hal yang bersifat kebaikan, bukan bertujuan untuk kejahatan.]

Keywords: ethics; blacksmiths; rituals

Copyright (c) 2020 by Karsa. All Right Reserved

DOI: $10.19105 /$ karsa.v28i1.2253 


\section{Introduction}

Ethics is not a new word for us. In fact, every activity of human life is inseparable from ethics because it is as an introduction to critical thinking that could distinguish what is a good or a bad thing, differentiate what is right or wrong and what is appropriate or inappropriate. We could take our own attitude about what must be done and ethics must also develop ways to implement ideas in their action. ${ }^{123}$ The understanding of the importance of ethics in human life needs to be followed up especially in running a business. Every Muslim must behave according to the concept of worship. ${ }^{4}$ Islam teaches people must hold on the norms and components of sharia values to perform actions. There are many Islamic ethics researches that will be used for busines. ${ }^{5}$

Whereas state the factors that influence infringement of business are irresponsible and interfering people's loss in order to minimize the disadvantage, lack of capital and knowledge, and control

1 Muatasim Ismaeel and Khatarina Blaim. "Practitioner Contribution: Toward Applied Islamic Business Ethics: Responsible Halal Business," Journal of Management Development 31 no. 10 (2012): 1090-1100.

2 Thomas Beschorner, "Ethical Theory and Business Practices: The Case of Discourse Ethics," Journal of Business Ethics (2006).

3 Zulkifli, Mohd Che, and Che Omar Ana Siti Sarpina Saripuddin, "Concept Of Business Ethics In Islam: Approach To The Entrepreneur," Journal of Asian Business Strategy 5 no. 1 (2015): 13-18.

${ }^{4}$ Rafik I. Beekun and Jamal A. Badawi, "Balancing Ethical Responsibility among Multiple Organizational Stakeholders," The Islamic Perspective Journal of Business Ethics 60 (2005): 131-145.

5 Arief Rahmani, Azmani, Karunia Puji Hastuti, and Parida Anggraini, "Upaya Pengrajin Pande besi Dalam menjaga Keberlangsungan Industri Kerajinan Rumah Tangga di Desa Tumbukan Banyu Dan Desa Sungai Pinang Kecamatan Daha Selatan Kabupaten Hulu Sungai Selatan," Jurnal Pendidikan Geografi 2 no.3 (2015): 66-80. 
of the authorities still weak ${ }^{6}{ }^{7}$ An individual business conducting in iron metal craftsman is called Pande Besi industry. In Madura, Pande Besi craftsmen are usually called as Tokang Pandhi (pande besi workers). Pande Besi itself is not only famous for its products and traditional production processes, but also as a place to repair sharp goods or damaged household goods. ${ }^{8}$

This research will focus on traditional Pande Besi. The topic was chosen because the production process is still traditional especially the craftsmanship filed on the heirlomms (master craftsman). Whereas not all Pande Besi in Paterongan Village has that expertise, there are four people who are classified as an expert. In this case, heirlooms business is a minority compared to other field businesses. We as native should contribute to keep and preserve the heirlooms such as spears and keris (Indonesia's traditional weapon) as the heritage of the kingdoms era in Indonesia through direct involvement or conducting research in that field.

Every business certainly has its own uniqueness and special characteristics, for example Marsyudi who is running the business Pande Besi. His company uses a sales system based on orders while other Pande Besi craftsman still apply a sales system by producing iron craft products every day. Marsyudi's business also is a right place to observe because the offered price of heirlooms is more expensive than other masters in the local village so it is necessary to explore that case. The production process of the heirloom contained elements of a cultural dimension or special rituals which have their own purposes.

\footnotetext{
${ }^{6}$ Sri Nawatmi, "Etika Bisnis Dalam Perspektif Islam," Fokus Ekonomi (FE) 9, no. 1 (2010): 50-58.

7 Mustaffa Mohamed Zain, Darus Faizah, and Aliza Ramli, "Islamic Ethical Practices and The Marketplace: Evidence From Islamic Financial Institutions," Procedia Economics and Finance 28 (2015): 266-273.

8 Restin Meilinia, "Faktor Yang Mempengaruhi Pelanggaran Etika Bisnis," Akademika 14, no. 2 (2016).
} 
This is very important to do a study related to the heirlooms whether the culture of business ethics are good or bad, right or wrong and appropriate or inappropriate.

The originality of this study is Pande Besi in applying sales transactions and producing heirlooms with teleology-based ethics. Teleology theory is to measure the good or bad action based on the objectives to be achieved by the action or based on the consequences caused by the action. Teleology is a study of symptoms that show regularity, design, aim, end, purpose, tendencies, goals, direction, and how these are achieved in a developmental process. ${ }^{9}$ Researcher is interested to observe on how the business ethics of Pande Besi in the field of craftsmanship at making heirlooms (master craftman) are associated with teleological theory?

\section{Methods}

This research used a qualitative research approach with a case study approach. ${ }^{10}$ This approach is used to provide evidence on decision making on Pande Besi business whether its business activities appropriate or inappropriate to be implemented. Next is Pande Besi has uniqueness compared to others. Its uniqueness is the sales system based on orders with a special ritual or cultural dimension caused the price is expensive but the buyer is still satisfied. The other Pande Besi produce every day so it does not have the characteristics on its production.

The main informants in the study are of Mr. Marsyudi as a business owner. His company has been operating for 33 years as an Pande Besi. There are 2 supporting informants, they are mr. Mustar

9 Zhai Changhong, "Research on Advertisement Translation from the Dual Perspective of Teleology \& Reception Aesthetics," 2nd International Conference on Education Reform and Modern Management. Atlantis Press (2015).

10 Ari Kamayanti, Metodologi Penelitian Kualitatif Akuntansi (Jakarta: Yayasan Rumah Peneleh, 2016). 
and mr. Sholeh. Mr. Mustar is a fixed employee for 10 years and the closest worker to Mr Marsyudi. The second informant is Mr. Sholeh as a non-permanent employee who has been working for 15 years. Mr. Sholeh works when there are many orders. Informant as other supporter is a buyer named mr. Ambri, he is a regular customer for almost 20 years.

Data collection in this study used unstructured interviews and observations. The unstructured interviews are used to get the profound information so there is no awkwardness in communication. Participant observation was conducting when mr. Marsyudi was making the heirlooms. This study used triangulation of data sources to prove the data obtained is valid by exploring the truth of certain information through various methods and sources of data acquisition by interviews and observations. Researcher used participant observation method, written documents, archives, historical documents, official notes, personal notes or writings and pictures or photos. Data analysis used comparative analysis tools which compared between the findings in the field and western ethical theory, theory of teleology.

\section{Result}

\section{The Emergence of Pande Besi}

Pande Besi came from Arosbaya. There was someone from Paterongan Village who helped make the sword and was thrown to the south then it was found at Bhuju' Batu Ampar in the local village. It is the derivation Pande Besi in the village of Paterongan. Pande Besi has existed since ancient era approximately in 1934. That heritage as a part of Madurese culture needs to be kept and preserved.

In contrast to Hilmi's research, he revealed the history of Pande Besi in Paterongan Village is a Kyai (religious figure) made the iron crafts as he wants with only wiping the iron into cloth. This history encouraged the inhabitants to make iron crafts using various kinds of 
traditional Pande Besi equipment. The existence of this history do not make the elders sure about Pande Besi in Peterongan Village. ${ }^{11}$

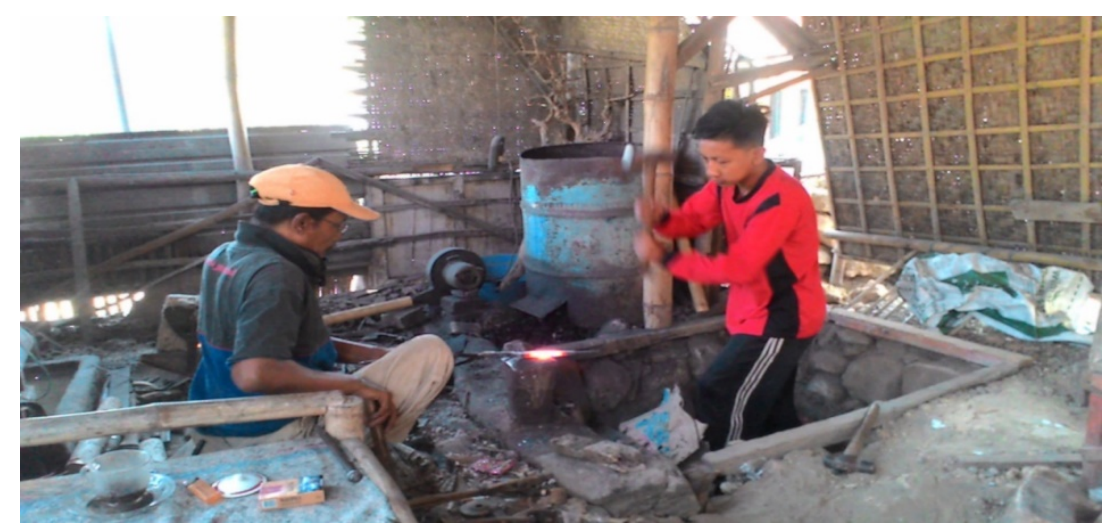

This manufacturing process is exhausting, requiring caution, agility and power to produce a high quality product.

\section{Pande Besi as a Way to Preserve the Heritage of the Kingdoms Era in Indonesia}

We also need to know who is the Pande Besi master, Pande Besi is someone who does the work making crafts for farming equipment made from iron and metal, by burning or flattening it until it is soft and the iron is forged and shaped as wished. ${ }^{12}$ Based on the results of observations and interviews with other Pande Besi in the Paterongan Village, they work using traditional equipment such as

${ }^{11}$ M. Hilmi, Sri Hidayanti, Peran Pekerja Perempuan Pada Industri Kerajinan Pandai Besi," Jurnal Tugas Akhir Universitas Trunojoyo Madura, accessed November 8, 2018. https://pta.trunojoyo.ac.id/wel come/ detail/110521100086.

12 S. Ann Dunham, Pendekar-Pendekar Besi Nusantara: Kajian Antropologi Tentang Pandai Besi Tradisional Di Indonesia (Bandung: Mizan, 2008). 
kowen, sapit, paron sungu, also hammer, emery, chisel, furnace, hand drill, hand grinding, grindstone and blower.

The raw material is scrap iron as the main material which is not pure but it has been processed into other products before such as railroads, ship plates or car plates. Meanwhile, charcoal as a supporting raw material used during the gilding or burning process. Coconut oil, water or chemical, and other materials needed as additional which will be useful in order to produce high quality products. The basic material for making the frame is wood. The types of wood got from the tree of guava, sapodilla, waru, mentaos and others, according to what is needed.

Another term for Pande Besi is iron craftsman who has various expertise including at making farm equipment, sharp weapons, and heirlooms. Heirloom objects are keris and spear. Meanwhile, farm equipment are sickles, hoes and others. The other creativities are swords, decorative sickles, and kitchen utensils such as knives. Iron craft has different name and pamor in each product. Pamor is derived from the word amor or awor means to blend. Pamor is also a decoration and used as a symbol of position or certain achievement during the kingdom era. Pamor is usually made of a type of metal called titanium taken from meteorite (broken pieces of meteors falled into the earth), the pamor material usuall has a unique white color and contrasts with iron or steel in a tosan aji or better known as a traditional weapon. ${ }^{13}$ However, researcher assumes pamor is a work of art painted on an iron craft using two layers, iron and meteor which is processed into interesting paintings. Pamor exists for its process and is known as painting, carving or art that has a variety of meanings, sparkling, and applied to keris and spears.

Once upon a time, Pande Besi was stated as a master because he could produce something magic only by rubbing the iron, whatever

${ }^{13}$ Ahmad Zazuli, Pamor Eksotik Tosan Aji (Solo: CV. Aneka, 2004).

Copyright (c) 2020 by Karsa. All Right Reserved DOI: $10.19105 /$ karsa.v28i1.2253 
item he wanted would be materialized. That nickname usually was used in the kingdom era. At that time, iron craft was needed as a weapon for war, farming, and carpentry tools. Someone said the craft master also could be called an expert at making heirlooms (sharp weapons) especially keris with an honorary title meaning "master". ${ }^{14}$ According to mr. Marsyudi, master is an expert at making heirlooms, but nowadays that nickname was rarely heard.

Mr. Marsyudi said he is an expert at making heirlooms through a long and difficult production process which is required accuracy, patience and perseverance in order to obtain good and high quality product. He also said orang pasaran (people who sell at the market) called him a master. The meaning of a master in this research is not magical person who is rubbing iron to make heirloom products, but someone who is an expert at making heirlooms by his own hands and needs various kinds of equipment and raw materials.

One of iron crafts is keris. In the past, keris was an heirloom besides as a sharp weapon. it also has a sacred and ceremonial value which is only owned by nobility and priyayi. ${ }^{15}$ Now, keris is an heirloom that has mystical, sacred elements and is believed to bring luck to the owner. Someone who has an heirloom is believed would be looked manly, handsome and is believed to bring luck and safety to the owner. Heirlooms are also used as decoration for display. The author urges heirlooms should be used for good things instead of crime for example, traditional ceremonial activities, accessory for groom's clothing, collections and so on. Nowdays an expert at making heirlooms is rarely found. Not many people make heirloom crafts as livelihood because the process requires a long time, strong stamina, and capital to produce a high quality product especially for complete set of heirloom. It makes people do not want to be iron craftsman.

\footnotetext{
${ }^{14}$ Bambang Marhijanto, Kamus Lengkap Bahasa Indonesia: Masa Kini (Surabaya: Terbit Terang, 1999).

${ }^{15}$ Mien Ahmad Rifai, Manusia Madura (Yogyakarta: Pilar Media, 2007).
} 
Therefore, heirloom crafts need to be preserved and do not become extinct by the time.

The explanation in the paragraph above is important because keris and spear are the symbols of the historical relics which are used for war. ${ }^{16}$ During the kingdom era, keris was owned by the nobility, the king and his descendants and used for characteristic weapon. Spears are used as weapons for royal warriors. Heirlooms are included in the category of traditional items which are the primary needs in the past. These statements are the reason why this heritage is very important for us as citizens of the Republic of Indonesia for always maintain and preserve it. These are the things that show to researcher about the reasons why this research specializes in the field of expertise at making heirlooms.

\section{Tatah, Tete, Tateb As a Business Mission}

Tatah, tete, and tateb are the words spoken by the master of Pande Besi when describing the characters must be had by person who is running a company. Tatah means diligent, tete is thorough. and tateb means appropriate. Entrepreneurs must be diligent, understand what the buyers want, serve them well, and build communiction. They also have to speak politely, do not lie and professional. Those three words are the missions of mr. Marsyudi's company and expected to satisfy customers and preserve culture.

\section{The Beginning of Transaction Based on Trust}

Down payment (DP) is a sign of order or a sign of agreement. The most of companies set a down payment for $50 \%$ to $75 \%$ of the total nominal payment, but $\mathrm{mr}$. Marsyudi does not set nominal amount to be paid though sometimes his company got an order cancellation. This case implies that company believes in customers. The application

\footnotetext{
${ }^{16}$ Akhmad Arif Musadad, "Makna Keris dan Pengaruhnya Terhadap Masyarakat di Surakarta," MIIPS 7, no. 2 (2008): 147-156.
} 
of the DP system by the Marsyudi's Pande Besi company aims to ensure the buyers are not trivial and as a sign they really want to order products. The following statements are stated by informant $(\mathrm{mr}$. Marsyudi): "pesse egebey DP lah, tanda jadi". "mesallah tak ngangguy $D p$ itu enteng meskewes kenal tetep bedheh DP, meske Rp10.000 lah seng penting aberri”.

Mr. Marsyudi said his company implements a down payment system which was used as a sign of order for the customers. The system is set up which the buyers would not be trivial even though they are his relation. Nominal of down payment is not set even if it is only IDR 10,000, this nominal is a small amount and no owners would take it while other companies set the nominal of DP approximately $50 \%$ to $75 \%$ of the total price. It concludes mr. Marsyudi gives the sense of trust to the customers. It was agreed by fixed worker (Mustars):

"Yes Miss. I do, so if someone decides to order, they have to pay first, at any cost, what's crucial is that there's money coming in. If there's no money coming in, miss, madam. The issue is that the individual isn't easy, then the money can be used to buy the iron, for extra capital".

Mustar said mr. Marsyudi implements a DP system with any nominal amount, the most important thing is the income. If there is no down payment then the order would be not processed because it is used as additional capital to buy needed raw iron. The statement of mr. Marsyudi above was also agreed by the customer (mr. Ambri):

"Iyeeh mejer Rp 100.000 dulu, kadang Rp 200.000, kadangkadang juga pernah bayar Rp 350.000, kasihan kalau gak dikasik dp dek. Soallah (soalnya) dibuat modal se (yang) aghebey (membuat) gheman (pusaka), bhejeren koli (kuli) nya juga. Kalau udah selesai dibayar semua." 
Mr. Ambri said he paid the down payment for ordered item to mr. Marsyudi for IDR 100,000 or IDR 200,000 and sometimes he paid for IDR 350,000. It is because the sense of pity that is embedded in the buyer to the seller and he understands the DP later would be needed as additional capital to buy raw material requirements and be used to pay workers' wages.

Then mr. Marsyudi said with this system sometimes he got order cancellation. In this case, the researcher assumes the buyers will be trivial and cancel as they want if he does not set a certain amount of DP budget. However, the cancelled item would be bought by other buyers. The interview with informant is down below (mr. Marsyudi): "Yeh mun jiyah la biasah, mesteh bedeh".

Mr. Marsyudi said there must be a buyer in debt. This phenomenon is a natural thing happens in business besides there are also people who pay their debts not on time but he understands them because the borrowers (creditors) does not have money so they have not been able to pay the debt. Here is the statement of mr. Marsyudi:

"Yeh tergantung kiyah (tertawa), tergantung kiyah jeyah, yeh se tak masok (yang gak bayar) yeh bedeh kiyah. Yeh epadhe'remma'ah oreng mun lok andhi' seekaghebey nyerra otangngah."

Mr. Marsyudi said the buyers pay the debt when they are able to pay. He also said buyers sometimes owed up to one year, some have even died. It crossed the mind of the researcher to ask the informant why he did not collect the debt so as buyers have not paid off their debt for a year. Here is the statement of the informant (Mr. Marsyudi):

Copyright (c) 2020 by Karsa. All Right Reserved DOI: $10.19105 /$ karsa.v28i1.2253 
“(...)Se penting engkok la mareh nagih deyyeh, yeh mun urusen majher apah enjhek terserah orengngah, la jhe' majher nyecel otangngah lok rapah, se penting majher deyyeh. Mun engkok lok endhe' wet ruwet marghe dunnyah, jhe' reng odhi' jeyah benne keng masalah pesse, tapeh amalan kebhaghusen se esambih, ajeyah se ghebey bekkal neng akherat. Mun pesse jeyah kenneng sareh, ajeyah mun can engkok. Yeh lok taoh can oreng se laennah."

("The important thing is I have asked them to pay, yes, it's up to the person to pay or not, pay in full or instalment, the most important is they paid off. I do not mind about money, our living is not all about money but doing goodness for our sake of hereafter. We can make money, that's my opinion. I do not know what others say")

Mr. Marsyudi claimed he had asked the buyers to pay off the debts but they do not be able to pay so he did not force them because he had empathy for others and was in the same position when the economy was not good. Therefore, he gave a leeway or grace period to others (creditors) in paying off their debts either by paying off the debt in full or by instalments.

It is confirmed by Mustar:

"Yeh mesteh etaghi mbak jhe' anyamah otang, keng oreng juwah bedhe se lok majher, lok andhi' pesse ghebey nyerra. Deddih paman lok maksa, se penting degghi' oreng ghelle' juwah nyerra, majher, la jhe' nyecellah lok rapah mbak".

("Yes, surely they will be asked to pay but still there are buyers who do not pay, they do not have money. So I do not force them, the important thing is they pay either in full or by instalments"). 
Mustar said debt must be asked but there are also debtors who have not paid because they have not been able to pay it so Mr. Marsyudi did not insist on forcing and give them another way to pay by instalment.

\section{Same Price for Heritage Sale Price}

Madurese do business in different ways but in giving prices to others there is different treatment such as giving a discounted price. It usually happens because they are family or fellow Madurese (if outside Madura) or also to the customer. it is different from the Marsyudi's traditional Pande Besi, he set the same price to both ordinary buyers and royal customers. It is because the process of making heirlooms is difficult, especially keris.

The process of making curves and pamor carvings are complicated so there is no different treatment in determining the sale price. It is also because the determination of the sale price of keris products depends on the difficulty level of pamor and its aesthetic elements. After setting the sale price, there will be a buy and sell transaction of heirloom products which the company gives the ordered product to the buyer with similarity in the calculation of the sale price that has been set according to the type of product and pamor the buyer wants.

We know that heirloom products, especially keris, is expensive because of their pamor techniques and aesthetic elements. The more interesting the heirloom products, the more expensive the price is. The more difficult the pamor requested, the more expensive the priceis . In this case, the price calculation at the traditional Pande Besi company of Marsyudi does not intend to deceive others or has the competitive price even in fact the price he offers is more expensive than other masters in the local village.

It could be seen from the raw materials used and the difficulty level of making pamor. Here is the conversation with the informant (Mr. Marsyudi): 
"Yeh lok berbohong ka oreng, misallah arghennah sekian yeh sekian, lok epategghi otabeh epakenne' megghi dhe' langganan(...).

("Yeah, we do not lie, if it is the price then it is, it is not raised or reduced even to the royal customer".)

Mr. Marsyudi's statement implied he does not lie about the price of the product to be sold to buyers, ordinary buyers or royal customers, the price is set according to the usual calculation without increasing or decreasing the price. Then mr. Marsyudi continued:

"Nah ajiyah se lok olle, kan manossah ajiyah bedhe se ajhegeh, se kobesah. Manossah jiyah kan esoro ngelakonih kebhagusan, yeh mun se lok bhegus yeh jhe' lakonih deyyeh".

("we have to be honest, we as humans are watched by God. Humans are told to be good, yeah, if it's not good, don't do that").

Mr. Marsyudi said he must be honest because God always takes care of every step of human beings, so we, as human, should do the good things and avoid the bad things, especially in working. It is agreed by the fixed worker (Mustars):

"Yeh mun din Bapak pagghun mbak arghennah, standard, tergantung dheri kualitas, dheri tingkat kesulitan dan kerumitan".

(Yes, the price of our products are standard, depending on the quality, the level of difficulty and complexity).

This was agreed by the additional worker (mr. Sholeh): 
"Gak ada bedanya mun arghe jiyah, sama. Jhe' aghebey pusaka jiyah melarat, engak kerres melarat juwah ghi' aghebey lok, kammah ghi' aghebey pamorrah pole".

(The price is same for all customers. The process for make the products are difficult such as keris. We have to make the curve and its pamor too).

Based on the two statements the price of the heirlooms is fixed, that is standard. It depends on the quality, level of difficulty and complexity at making the pamor as the buyer wants. The more difficult the pamor is made, the more expensive the price.

\section{Discussion}

\section{Jhejeh Ritual as Determination of Production Time and Date}

Jhejeh means luck. On the process of making heirlooms, jhejeh is very important because it will produce the high quality of iron crafts especially keris and spears, for some people could not produce any items without jhejeh. Other benefits are believed the craftsman would be safe and the owner would be luck. Besides getting those benefits, jhejeh is also useful to know when the product should be finished on making it. In this case, jhejeh is used to find out what day and date the production would be taken so craftsman later could finish the product at that time but it is also according to the request of buyer and the agreement between buyer and seller. Jhejeh for Pande Besi is believed to be beneficial when running out that business, the craftsman would be safe and get high quality products.

Marsyudi's Pande Besi always does jhejeh as a habit when they want to produce good and beautiful heirlooms in other words of high quality and avoid the risk of accidents and bad effects as he said with his language "biar yang megang tidak sial" (The owner to be is avoided from misfortune). The implementation of jhejeh later would be used as an estimate of the time when the product should be finished 
but still according to buyer's wants and the agreement between the two parties. The interview with informant is down below (mr. Marsyudi):

"If according to the master (pointing out himself) the schedule is not determined whether what day or time will work for making keris, Pande Besi does Jhejeh ritual to determine a luck day and date so as the owner will be avoided from misfortune and the worker will be safe. The working hours usually start at 07:00 to 17:00 o'clock in the afternoon, from 12:00 to 13:00 pm for rest and pray. The time start to work is not determined, sometimes at 8 or at 9. It is because we have to find the right time and date".

Mr. Marsyudi said his Pande Besi's schedule is determined by doing jhejeh, which means luck is used to determine the exact date and time of production in the hope that the craftsman is given safety by God and aims for the owner would be avoided from misfortune. In addition the products have high quality. Because the time of production is determined by jhejeh, the work schedule is uncertain, sometimes start at 8 am or 9 am but the workers have to be in the company at $07.00-17.00$.

For researcher the word jhejeh is a new word and needs more explanation. What is the purpose of jhejeh? is the production always in accordance with the jhejeh policy? Here is the informant's statement (mr. Marsyudi):

"We have promised to customers, what they want, adjusting to the agreement, according to the right date and date. They choose the time and date, is it good to take this day and date. Determination of the primbon (traditionql forecasting). Then want to be taken one week or 10 days later, must be in accordance to the request of customer." 
Mr. Marsyudi stated he completed the order according to the customer's request, agreement between them, and according to Jhejeh's determination for the right day and date to produce the heirlooms. Jhejeh is one of the rituals before making heirlooms which aims for the sake together because Jhejeh is used and believed in determining good day and date for producing items. For those who are unfamiliar to keris and Pande Besi, it sounds unreasonable and not related to the time to produce items because they trust that all days and dates are good, nothing bad. It is one of the cultures that has been carried out by Marsyudi's traditional Pande Besi for generations. It is agreed by fixed worker (Mustar ):

"Yeh mun ajeyah jeh mbak, tergantung jhureghennah, jhuregennah terro areh apah yeh man Marsyudi pas aghebeyyagin, tapeh ajeyah ekarembhe', koca'eng na'kana' sakola'an ruwah komunikasi sebelum aghebey. Se nyaman areh apah mun aghebey, kol berempah se nyaman deyyeh ruwah. Mun ajeyah mbak la apa yeh nyamannah,,, budaya, ajeyah la dheri lambhe' mbak(...)".

("Yeah, all is depends on the customers, if they want on the exact day then mr. Marsyudi will make it but it has to discuss before, if using kids term 'communication before making'. What is the good day and date then we will do it at that time. How to say it sis? Cultures, it is from the past") (...)).

It is also agreed by addition worker (mr. Shoeh):

"Iyeh, kan sebelum eteremah pessenannah oreng juwah yeh kakak ngoca' jhe' ghi' bennyak pessennan se ngadhe' dheri sampean, deddih bisa ekala' sebulen agghi' otabeh 3 minggu agghi'. Biasannah ngoca' deyyeh. Sesuai kesepakatan". 
(Yeah, before we take the new order from the same person, we would say many orders from you and you can take it in one month or three weeks. All is just by agreement).

Based on those two statements we can conclude jhejeh is implemented long time before, it is a habit and become a culture. In addition, ordered product is made according to the customer's request and agreement between two parties for taking the products because they need time to do Jhejeh ritual (luck). Mr. Marsyudi's statement is agreed by customer (mr. Ambri): "10 hari, ini saya yang pessen sudah 10 hari sama sekarang, sudah selesai 10 hari itu". ("ten days, I ordered the item ten days before and it is finished on that time".)

\section{The Ritual Distribution of Porridge or Sticky Rice As A Symbol of Self-Defense For Safety During Production}

The rituals in producing a keris are ancestral habits which has become a culture. We could apply it into our daily activities even in business as long as the goal or intention does not endanger ourselves or others then we could find the benefits . For example is the ritual on producing heirlooms. We often hear about the work culture of Pande Besi craftsman especially in the field of expertise at making heirlooms such as keris. The ritual is carried out by the Marsyudi's Pande Besi business gives porridge or sticky rice to others with the aim for safety while working, keeps the relationship and gives alms. However, the ritual headlines are performed for self-defense and believed that the owner would not be fortuneless. The following is the explanation from an informant (mr. Marsyudi):

"Before making the keris, we do selametan (traditional activity such as giving foods to neighbour or pray together), during selametan there should be provided sesajen (offerings) like flowers and incense if necessary. But the important thing is 
sticky rice or starch and give it to kyai, orphans or poor people so as safety during working, then for keep the relationship".

Mr. Marsyudi told before making a keris, the first thing to do was selametan activity by providing porridge or sticky rice, preparing flowers and incense if necessary, it could be called sesajen. After all the ritual equipments have been prepared, then give the porridge to publc figure such as Kyai. Do not forget give it to orphans and people in need with the aim or intention that people who are involved in the work of keris production would be safe. Another aim is to keep the relationship and give alms. Here is the statement: "Yeah, for giving alms too"

The author also asked about the other rituals: "We recite basmalah when start the work in order to be safe, then if keris is completed, we water it with flower water". The explanation from the informant above mentioned the other rituals are reciting basmalah when going to do work and watering the keris with the water of flowers. Why should water it with flower water? Does it have the effect on the quality? Here is the answer of the informant (mr. Marsyudi): "yeah the way it is, watering the keris with flower water".

Mr. Marsyudi's statement above does not answer the question about the reason why the keris is watered with flower water. Researcher asked the second time where is the culture from. the informant answered: "Yes, that's the way it used to be." Mr. Marsyudi claimed there are rituals in making heirlooms, especially keris such as selametan activity by giving sticky rice or porridge before starting to produce. The next ritual is watering the heirloom with flower water after the heirloom is produced. The answer from the informant is only a confirmation of the previous question. Based on information obtained from an article, heirlooms are usually bathed at a certain time such as the owner clean the heirloom and charge the energy at one syura (traditional month calendar). At that time it was also for cleaning rusted heirlooms with special oils such as misik oil, jafaron oil, jamas 
oil, sandalwood oil and others. The equipments need to be prepared are flowers, offerings, and incense in this bathing ceremony.

The thing to remember in this ritual is praying for master Therefore, heirloom collectors should not assume that an object can make them rich, authoritative or get high position because the real power is God who makes a person rich, dignified and authoritative through the prayers from the master, not from the object. Ethics is a necessary in a business, without ethics in the business itself, it would not run well. Ethics itself cannot be separated from business. The application of business ethics in every business is different, a business has its own business ethics, it does not always rely on theories they do not understand. As long as the ethics they applied is good, the business practices will run well.

\section{Conclusion}

The ethics applied in the business have similarity in concept, especially the transactions activity but there are also differences in practices that are not found in teleological ethics theory. There are basic values business ethics of Marsyudi's traditional Pande Besi and the application of culture or rituals before producing heirlooms. These differences are common because business is not always about material and quantitatively calculated. It happens in a Pande Besi business that has its own way of implementing the ethics. First, Marsyudi's traditional Pande Besi business applies the value of trust in the down payment system, giving equal heirloom sale price and giving two options to pay both credit and full payment transactions. Second, the application of ritual ethics before conducting heirloom production. The rituals are jhejeh rituals, giving porridge or sticky rice, reading basmalah and watering the keris using flower water. All of those rituals are intended for the safety of craftsmen and produce the high quality heirloom products. Those findings are in line with teleology 
theory because the purpose of its business ethics for a good thing. The business activities is allowed to operate according to teleogical theory.

The information about determination the price in making pamor was quite difficult to get and to estimate how much the profit. Researcher also obtained a little information about the step of rituals and could not explain more as it is a habit for Marsyudi's company. This research is expected to be used as a contribution, especially for the next researchers who want to find out other uniqueness about the culture in the other Pande Besi such as farming equipment or carpentry tools using phenomenological method. Next researchers could observe more about how the computation ethics of pamor has various price. They also could observe the other rituals or cultures ethics.

\section{Bibliography}

Azis, Abdul. Etika Bisnis Perspektif Islam: Implementasi Etika Islami Untuk Dunia Usaha. Bandung: Alfabeta, 2013.

Azmani, Arief Rahmani, Karunia Puji Hastuti, and Parida Anggraini. "Upaya Pengrajin Pandai Besi dalam menjaga Keberlangsungan Industri Kerajinan Rumah Tangga di Desa Tumbukan Banyu Dan Desa Sungai Pinang Kecamatan Daha Selatan Kabupaten Hulu Sungai Selatan." Jurnal Pendidikan Geografi (2015): 66-80.

BPS. "Kecamatan Galis dalam Angka." Badan Pusat Statistik Kabupaten Bangkalan. last modified on March 1, 2018. https://bangkalankab.bps.go.id/publication/2018/10/05/a7b4b4 2b4b0f4a6bd5004ad3/kecamatan-galis-dalam-angka-2018

Beekun, Rafik I, and Jamal A Badawi. "Balancing Ethical Responsibility among Multiple Organizational Stakeholders: The Islamic Perspective." Journal of Business Ethics (2005): 131-145. 
Beschorner, Thomas. "Ethical Theory and Business Practices:The Case of Discourse Ethics." Journal of Business Ethics (2006): 127-139.

Blog Desa. "KKN Universitas Trunojoyo Madura." paterongan. blogdesa.net. last modified November 6, 2018. http://pate rongan.blogdesa.net/2016/08/legenda-dan-sejarah-desa.html

Creswell, John W. Research Design: Pendekatan Kualitatif, Kuantitatif dan Mixed: Edisi Ketiga. Yogyakarta: Pustaka Pelajar, 2013.

Dunham, S. Ann. Pendekar-Pendekar Besi Nusantara: Kajian Antropologi Tentang Pandai Besi Tradisional di Indonesia. Bandung: Mizan, 2008.

Endrawati, Endah. "Posisi Keris Pada Masyarakat Jogja Modern." Jurnal Komunikasi 7, no. 2 (2015): 137-151.

Hamka. Pandangan Hidup Muslim. Jakarta: Gema Insani, 2016.

Hamzah, Yaksan, and Hafid Hamzah. Etika Bisnis Isla. Makassar: KRETAKUPA Print, 2014.

Hilmi, M, and Sri Hidayanti. "Peran Pekerja Perempuan Pada Industri Kerajinan Pandai Besi." Jurnal Tugas Akhir Universitas Trunojoyo Madura (2018).

Ismaeel, Muatasim, and Khatarina Blaim. "Practitioner Contribution: Toward Applied Islamic Business Ethics: Responsible Halal Business." Journal of Management Development 31, no. 10 (2012): 1090-1100.

Issoufou, Chaibou. "Review Article: Significance of Islamic Business Ethics." International Journal of Current Research 7, no. 11 (2015): 23362-23364.

Kamayanti, Ari. Metodologi Penelitian Kualitatif Akuntansi. Jakarta: Yayasan Rumah Peneleh, 2016.

Kurnia, Ekasari. "Hermeneutika Laba Dalam Perspektif Islam." Jurnal Akuntansi Multiparadigma 5, no. 1 (2014): 67-75. 
Liputan6. "Temuan 4 Zat Berbahaya dalam Makanan, Dari Permen Hingga Ikan Teri." Accessed May 6, 2018. https://www. liputan6.com/regional/read/3541845/temuan-4-zat-berbahayadalam-makanan-dari-permen-hingga-ikan-teri?source=search

Liputan6. "Temuan Bakso Mengandung Babi, DPRD Tegur Dinkes Pekanbaru." Accessed May 6, 2018. https://www.liputan6.com/ regional/read/3075992/temuan-bakso-mengandung-babi-dprdtegur-dinkes-pekanbaru? source $=$ search

Marhijanto, Bambang. Kamus Lengkap Bahasa Indonesia: Masa Kini. Surabaya: Terbit Terang, 1999.

Mawaddah, Nurul, and Indra Wijaya. "Relevansi Nilai Etika Bisnis dalam Ruang Lingkup Akuntansi Syariah." Jurnal Ekonomi dan Kebijakan Publik 3, no. 1 (2016): 34-48.

Meilinia, Restin. "Faktor Yang Mempengaruhi Pelanggaran Etika Bisnis." Akademika 14, no. 2 (2016).

Moleong, Lexy J. Metodologi Penelitian Kualitatif. Bandung: PT Remaja Rosdakarya, 2014.

Muhammad, Mohd Zulkifli, Azleen Illiasi, Mohd Fahmi Ghazali, Rosita Chong Abdullah, and Hanudin Amin. "An Analysis Of Islamic Ethics In Small And Medium Enterprises (SMEs)." UNITAR E-Journal 4, no. 1 (2008): 46-58.

Musadad, Akhmad Arif. "Makna Keris dan Pengaruhnya Terhadap Masyarakat di Surakarta." MIIPS 7, no. 2 (2008): 147-156.

Nawatmi, Sri. "Etika Bisnis Dalam Perspektif Islam." Fokus Ekonomi (FE) 9, no. 1 (2010): 50-58.

Novitasari, Asnia. "Praktik Bisnis Pengusaha Muslim Tionghoa Di

Solo dalam Perspektif Etika Bisnis Islam." MA Thesis, 2016: $1-108$.

Nurpeni. “Analisis Tentang Kendala Ibu Rumah Tangga Enggan Berwirausaha di Kelurahan Umban Sari Kecamatan Rumbai Kota Pekanbaru." Jurnal Ekonomi dan Bisnis 7, no. 2 (2010). 
Okezonenews. "Malam satu suro, waktu yang pas memandikan benda pusaka." Accessed November 11, 2018. https://news.okezone.com/read/2017/09/20/519/1780062/mala m-satu-suro-waktuyang-pas-memandikan-benda-pusaka

Oktasari, Orin. "Bisnis Kosmetik Dalam Etika Bisnis Islam." $A L$ INTAJ 4, no. 1 (2018): 18-33.

Pusaka, Dunia. "Dunia Pusaka. Kegunaan Keris Singo Barong Kuno Berkhasiat Ampuh.” Accessed November 11, 2018. http:// www.duniapusaka.com/pusakaterjual/kegunaankerissingobaron g-kuno-berkhasiat-ampuh

Pusaka, Dunia. Dunia Pusaka. Kerajaan Blambangan. Accessed November 08, 2018. http://www.duniapusaka.com/blog/kera jaan-blambangan

Putri, Silvi Rosdiana Rahman. "Etika Bisnis Pengusaha Muslim dalam Membangun Loyalitas Pelanggan di Toko LA Surabaya." Undergraduate Thesis, Universitas Islam Negeri Sunan Ampel, 2017.

Rifai, Mien Ahmad. Manusia Madura. Yogyakarta: Pilar Media, 2007.

Rivai, Veithzal, Amiur Nuruddin, and Faisar Ananda. Islamic Business And Economic Ethics: Mengacu Pada Al-Quran Dan Mengikuti Jejak Rasulullah SAW dalam Bisnis, Keuangan, dan Ekonomi. Jakarta: PT Bumi Aksara, 2012.

Sampurno, Wahyu Mijil. "Penerapan Etika Bisnis Islam dan Dampaknya Terhadap Kemajuan Bisnis Industri Rumah Tangga." Journal of Islamic Economics Lariba 2, no. 1 (2016): 13-18.

Sugiyono. Metode Penelitian Bisnis. Jakarta: Alfabeta, 1999.

Warto. "Makna Desain Keris Dalam Budaya Jawa." Komunika 2, no. 1 (2008): 113-129.

Zain, Mustaffa Mohamed, Darus Faizah, and Aliza Ramli. "Islamic Ethical Practices and The Marketplace: Evidence From Islamic 
Financial Institutions." Procedia Economics and Finance 28 (2015): 266-273.

Zazuli, Ahmad. Pamor Eksotik Tosan Aji. Solo: CV. Aneka, 2004.

Zhai, Changhong. "Research on Advertisement Translation from the Dual Perspective of Teleology \& Reception Aesthetics." $2^{\text {nd }}$ International Conference on Education Reform and Modern Management. Atlantis Press, 2015. https://doi.org/10.2991/ ermm-15.2015.78

Zulkifli, Mohd Che, and Che Omar Ana Siti Sarpina Saripuddin. "Concept of Business Ethics in Islam: Approach To The Entrepreneur." Journal of Asian Business Strategy 5, no. 1 (2015): 13-18. 